\title{
Hydrocarbon-induced magnetic contrasts in some Venezuelan and Colombian oil wells
}

\author{
Vincenzo Costanzo-Alvarez ${ }^{1}$, Milagrosa Aldana $^{1}$, Marisel Díaz ${ }^{2}$, Germán Bayona $^{3}$, and Carolina Ayala ${ }^{1,3}$ \\ ${ }^{1}$ Departamento de Ciencias de la Tierra, Universidad Simón Bolívar, Apartado 89000, Caracas 1081-A, Venezuela \\ ${ }^{2}$ Centro de Física, Instituto Venezolano de Investigaciones Científicas, IVIC, Apartado 21827, Caracas 1020-A, Venezuela \\ ${ }^{3}$ Corporación Geológica ARES, Calle 116, No 14A06, Bogotá, Colombia
}

(Received December 1, 2005; Revised June 22, 2006; Accepted July 7, 2006; Online published November 8, 2006)

\begin{abstract}
In this work we present a review of our current research on the subject of near-surface hydrocarbon-induced magnetic contrasts. Samples are drill cuttings from number of Venezuelan and Colombian oil fields, and some soils from an oil prospective area. Results from rock magnetic, electronic paramagnetic resonance (EPR), extractable organic matter (EOM) and scanning electron microscopy (SEM) are discussed in light of new experiments. Two types of magnetic susceptibility (MS) anomalies have been recognized in oil well samples (i.e. A and B-like). A-like anomalies are probably associated to a reducing environment caused by the underlying reservoirs, whereas B-like anomalies might reflect lithological contrasts. Samples from A-like anomalous levels reveal the restrictive presence of authigenic spherical aggregates of submicronic Fe-rich magnetic crystals. Peaks of organic matter free radical concentration (OMFRC) and EOM are also observed at depth levels that lie close to those with A-like anomalies. Hysteresis ratios $J_{r s} / J_{s}$ and $H_{c r} / H_{c}$ could be used as additional criteria to recognize A-like magnetic contrasts. In soil samples, MS and OMFRC anomalies coincide with peaks of ethane concentration and an area underneath where source rock has reached appropriate conditions of pressure and temperature to generate hydrocarbons (Cretaceous kitchen). Different types of crude oils and subsurface structures could have also a direct effect on the observed amplitude of A-like anomalies.
\end{abstract}

Key words: Drill cuttings, magnetic susceptibility, framboids, SEM, EPR, EOM.

\section{Introduction}

In the last few decades, high resolution aeromagnetic surveys over oil fields, and direct magnetic susceptibility (MS) measurements in soils, sediments, and drill cuttings, have been proposed as possible methods to detect low amplitude anomalous magnetizations. Such anomalies might be produced by shallow and atypical concentrations of authigenic magnetite and/or Fe-sulphides, resulting from the chemical alteration of primary Fe-oxides in redox conditions induced by the underlying reservoir. (e.g. Foote, 1984, 1987, 1992, 1996; Saunders and Terry, 1985; Saunders et al., 1991, 1999). The effects of these secondary magnetic phases might be critical in magnetostratigraphic and paleomagnetic studies as well. In fact, primary magnetizations in sedimentary basins could be partially or totally overprinted by late thermochemical events produced, not only by fluid motions associated to orogenic events, but also by the migration of oil and gas (Hall and Evans, 1995).

Benthiem and Elmore (1987), McCabe et al. (1987) and Elmore et al. (1987, 1993) have identified, by scanning electronic microscopy (SEM), spherical aggregates of submicronic crystals of magnetite associated to solid bitumen and speleothems with hydrocarbon inclusions. These aggregates appear to be linked to crude oil biodegradation

Copyright (c) The Society of Geomagnetism and Earth, Planetary and Space Sciences (SGEPSS); The Seismological Society of Japan; The Volcanological Society of Japan; The Geodetic Society of Japan; The Japanese Society for Planetary Sciences; TERRAPUB.
(McCabe et al., 1987; Elmore et al., 1987) or to inorganic chemical processes due to the presence of hydrocarbons (Elmore et al., 1993).

Most of our research projects, developed since 1998, have dealt with these lines of investigation, namely the study of near-surface magnetic contrasts over oil fields as alternative means of assessing hydrocarbon reservoirs (e.g. Aldana et al., 1999; Costanzo-Alvarez et al., 2000; Díaz et al., 2000). In order to examine the causal relationship, between hydrocarbons and spherical aggregates of Ferich minerals, our rock magnetic results have been complemented by analyses of small concentrations of organic matter free radicals (OMFRC) via Electron Paramagnetic Resonance (EPR), and extractable organic matter (EOM). The samples used are drill cuttings from different depth levels of either producer or non-producer wells located in the Guafita and La Victoria oil fields (southwestern Venezuela). More recently, we have also studied soil samples from an oil prospective area (southwestern Venezuela) by comparing rock magnetic and EPR results with ethane gas analyses and remote sensing data (Gonzalez et al., 2002).

In this paper we present a review of our previous works (Aldana et al., 1999; Costanzo-Alvarez et al., 2000; Díaz et al., 2000; Gonzalez et al., 2002; Aldana et al., 2003) in light of new rock magnetic analyses performed at the Institute of Rock Magnetism (IRM) in Minnesota. We also report unpublished EOM data for some Guafita and La Victoria oil wells. Rock magnetic data obtained at the IRM 
(i.e. low temperature susceptibility measurements and room temperature hysteresis parameters) are intended to characterize the degree of magnetite oxidation and to better understand the nature of the chemical processes involved in the hydrocarbon-induced magnetic authigenesis. Finally, we discuss preliminary results for some Colombian oil wells located in the vicinity of the Guafita oil field and further south in the Llanos basin of Colombia (i.e. Caño Limón and Castilla respectively). Some of these wells hold contrasting settings with different types of crude oil (biodegraded and light) and distinct subsurface structures that might have a direct effect on hydrocarbon migration and/or seepage from source rocks and traps.

\section{Sampling and Experimental Techniques}

In view of the fact that our research has focused on the near-surface expression of hydrocarbon migration, the drill cuttings analysed in La Victoria, Guafita (Venezuela) and Colombian oil wells have been taken far above from the reservoirs. For this reason, sampling intervals of about 15 meters are restricted to the initial 100 to 1500 meters of each well.

Throughout the drilling process, a lubrication viscous mud is pumped down along the column of a round hollow pipe attached to a core barrel. The drilling muds employed are free of magnetic contaminants. They are all waterbased, with bentonite clay, calcium carbonate and/or barium sulfate to add viscosity to the mixture. The mud flows out through the holes of the core barrel carrying rock cuttings that are filtered, cleaned off using running water and collected. The travel-times of these cuttings up to the surface are continuously recorded in a computer. These data, together with the specifications of the mud employed, are used to determine the depth ranges corresponding to each drill cutting. At the end, a depth interval of approximately $15 \pm 2$ meters per sample is obtained instead of a discrete depth level. We labelled each drill cutting with the top level of its corresponding depth interval.

Key data to study and characterize magnetic contrasts over oil fields are room temperature MS logs, EPR to precisely determine OMFRC, EOM and SEM analyses coupled with X-ray energy dispersion (EDX). Some of these results are complemented with S-ratio logs $\left(\mathrm{IRM}_{-0.1 \mathrm{~T}} / \mathrm{SIRM}_{+3 \mathrm{~T}}\right)$, X-ray diffraction, petrographic analyses at magnifications of $8 \mathrm{X}$ to $66 \mathrm{X}$, IRM acquisition and high-temperature and low temperature susceptibility curves .

Room temperature MS measurements were performed in a Sapphire SI-2 and a Bartington susceptometer with a dual frequency of the applied field. We did not find significant differences between high and low frequency susceptibility measurements, precluding therefore the possibility of identifying by this means the presence of fine-grained magnetic contaminants coming from the core barrel.

We also carried out thermomagnetic susceptibility measurements in air for some representative samples. The equipment used was a Bartington MS2 with a MS2W probe that allows continuous susceptibility and temperature readings of a sample heated, up to $700^{\circ} \mathrm{C}$, in a SM2WF furnace. The MS2W has an operational frequency of $696 \mathrm{~Hz}$ and a precision of $4 \pi \times 10^{-6}$ SI per $10^{-5} \mathrm{~m}^{3}$.

The instrument used for the SEM studies was a Phillips scanner SEM 505 with an EDAX PV 9100/60 X-ray dispersion analyzer. The SEM photomicrographs are topographic images of secondary electrons. SEM analyses were performed on magnetic separates obtained by applying a hand magnet to a suspension in acetone of finely ground drill cuttings. In order to disperse these small amounts of sample they were mixed with ethanol and exposed to an ultrasonic bath for approximately 5 minutes. A drop of this preparation was placed on a thin layer of polyethylene set on a carbon holder, and covered by a carbon film $(\sim 10 \mathrm{~nm})$.

The EPR technique, employed to measure OMFRC, was applied at room temperature using a Bruker EMX spectrometer that works in the X-band $(\nu \sim 9.8 \mathrm{GHz})$, with a rectangular cavity and $100 \mathrm{kHz}$ modulation. Experimental conditions (microwave power and modulation amplitude) were adjusted to avoid saturation effects. For each well analysed we selected about 10 representative depth levels in order to carry out the EPR experiments. The samples used in these measurements were pulverized to less than 150 mesh in order to homogenize them.

The EPR spectrum consists of the first derivative of the energy absorbed as a function of the magnetic field strength. The quantity that measures the number of spins is the area beneath the absorption curve. This technique is characterized by its high sensitivity and element specificity allowing the detection of very small amounts (i.e. ppm) of paramagnetic entities.

Some applications of the EPR technique to earth sciences include trace metal analysis in different environments (Burguess et al., 1975; Boughriet et al., 1992) and dating of carbonate rocks (Jonas, 1997; Rink, 1997). In addition, the EPR technique has been applied to the study of clay minerals (Meads and Malden, 1975; Angel and Vincent, 1978; Hall, 1980); dolomites (Lumsden and Lloyd, 1988; Granwehr et al., 2004), volcanic ashes (Pawse et al., 1998), sedimentary organic matter (Aizaenshtat et al., 1986; Díaz et al., 2000; Gonzalez et al., 2002) and marine sediments (Otamendi et al., 2006).

To obtain the EOM fraction, samples from MS anomalous and non anomalous levels were pulverized to less than 150 mesh, weighed and treated with $\mathrm{CHCl}_{3}$, at room temperature, in a stirrer for about 40 minutes. The extract was transferred to a beaker and dried in order to obtain the milligrams of EOM per gram of sample. The rest of sample, without EOM, was dried too for further EPR measurements.

New OMFRC and EOM data reported in this study are: OMFRC results for oil well GF-3X (Guafita), Castilla 30 (Colombia) and Caño Limón 3 (Colombia) and EOM results for oil wells LVT-4X (La Victoria), GF-3X, GF-8X (Guafita), Castilla 30 and Caño Limón 3.

In this work we also present additional rock magnetic results for some of La Victoria and Guafita oil wells, namely MS log for oil well GF-3X, thermomagnetic susceptibility curves for oil wells LVT-4X, GF-3X and GF-8X, low temperature susceptibility curves for LVT-4X and GF-3X and hysteresis ratios $J_{r s} / J_{s}$ and $H_{c r} / H_{c}$, measured in whole rock drill cuttings from a number of Guafita oil wells. Some of these experiments were performed at the Institute of Rock 


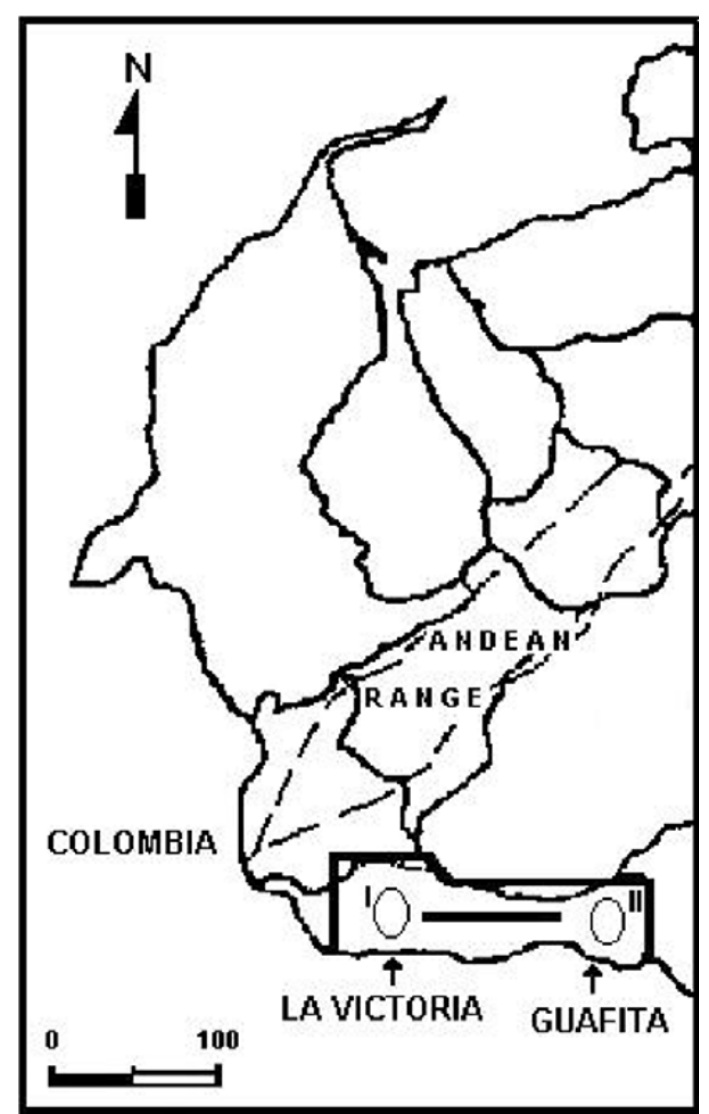

Fig. 1. Location of La Victoria and Guafita oil fields in southwestern Venezuela.

Magnetism (University of Minnesota). They include low temperature susceptibility measurements to identify stoichiometric or cation-deficient magnetite (MPMS2 cryogenic susceptometer), high temperature susceptibility measurements (Geofyzika KLY-2 KappaBridge AC Susceptibility Bridge) and room temperature hysteresis loops to further characterize magnetic minerals and domain state (Princeton Applied Research Vibrating Sample Magnetometer).

We also present new rock magnetic results from the two Colombian wells Castilla 30 and Caño Limón 3, namely MS log and continuous heating susceptibility curves.

\section{Geological Setting of La Victoria and Guafita Oil Fields}

La Victoria and Guafita oil fields are located in southwestern Venezuela, in the Apure-Barinas sedimentary Basin (Fig. 1).

Hydrocarbons of La Victoria and Guafita have gravity values ranging from $30^{\circ}$ to $36^{\circ}$ API. Mathematical simulations of the origin of these hydrocarbons, calibrated with petrophysical information from oil wells (Chigné, 1985), suggest that the oil was produced at the deepest southwestern part of the basin ca. 12 Ma ago (mid-Miocene). However, the peak of oil generation was probably reached ca. 3.8 Ma ago (Pliocene), when the sedimentary section reached a thickness of approximately $6600 \mathrm{~m}$.

Samples for this study belong to a single group of molasses of fluvial-delta provenance, which comprises the filling of the Apure-Barinas basin and had their origin dur- ing the uplift of the Andean Range during Miocene to MidPliocene times (Guayabo Group, Rio Yuca/Parangula Formation). The sediments of the Guayabo Group have been divided in two major sequences (Gonzalez de Juana et al., 1980), namely a basal layer of conglomerates with needleshaped grains of quartz, cherts and poorly sorted coarsegrained sandstones, capped by a top layer of fine-grained bleached sandstones and grey and mottled clays. Most of the lithologies we have studied, for the near-surface strata of La Victoria and Guafita oil wells, correspond solely to the upper section of the Guayabo Group. They are homogeneous yellow to brownish sandstones without visible compositional differences between the various samples analysed.

\section{Rock Magnetic, EPR and EOM Results from La Victoria and Guafita Oil Fields}

Aldana et al. (1999) and Costanzo-Alvarez et al. (2000) have previously studied near-surface magnetic contrasts (MS positive anomalies) in a number of oil wells located in La Victoria (3) and Guafita (11) fields. There is a clear distinction between two kinds of MS positive contrasts, namely: anomaly $\mathrm{A}$ that seems to result from a reducing environment induced by an underlying reservoir, and anomaly B that might reflect a lithological contrast (detrital or diagenetic). Such a categorization is also supported by preliminary petrographic and X-ray diffraction analyses (Costanzo-Alvarez et al., 2000). A-like anomalies are mainly observed in producer wells and appear to be related to the presence of spherical aggregates of authigenic submicronic Fe-rich (Ti-poor) magnetic grains, identified by SEM analyses. In non-producer wells A-like anomalies have been explained by Aldana et al . (1999) as the fossil documentation of the occurrence of hydrocarbons in the past, and their migration toward their present position in the reservoir.

On the other hand, for samples from B-like anomalous levels, no spherical aggregates of submicronic Fe-rich (Tipoor) magnetic grains have been recognized whatsoever.

Additional data such as S-ratio logs (IRM-0.1 T/ SIRM $_{+3 \mathrm{~T}}$ ), X-ray energy dispersion (EDX) analyses, isothermal remanent magnetization (IRM) acquisition curves and high-temperature susceptibility measurements, seem to indicate that a low-coercivity mineral (e.g. magnetite) is the dominant magnetic phase in most A and B-like anomalous levels (Aldana et al., 1999; Costanzo-Alvarez et al., 2000).

To further typify magnetic contrasts in La Victoria and Guafita fields, EPR analyses have been used looking for traces of OMFRC (Díaz et al., 2000). There is always an OMFRC peak close to those levels where anomaly A has been identified. Chloroform treatments were carried out to obtain the EOM and to determine whether free radicals are associated to non-extractable organic matter (e.g. kerogen) or to extractable organic matter (e.g. asphaltene). EPR measurements show that, in most cases, there is not difference between chloroform treated and untreated samples, precluding thus the presence of asphaltenes. These results also suggest that free radicals correspond exclusively to kerogen. Asphaltenes are highly resistant to microbial attack 

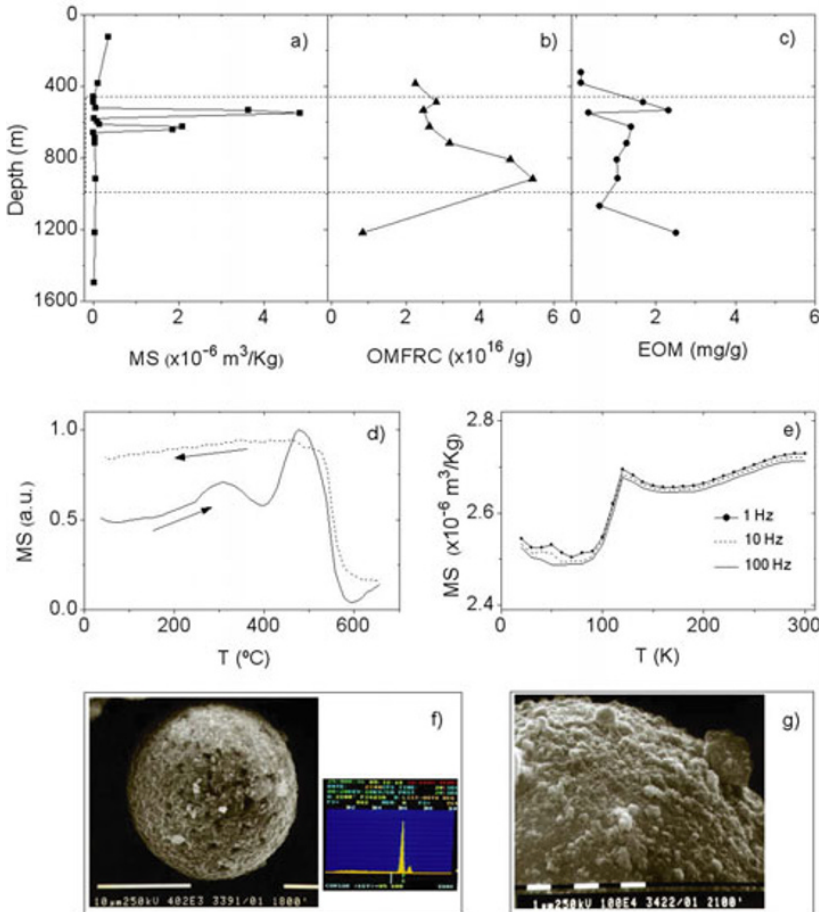

Fig. 2. A-like MS anomaly for producer well LVT-4X: (a) Magnetic susceptibility (MS) (after Aldana et al., 1999), (b) Organic matter free radical concentration in spin/gr (OMFRC) (after Diaz et al, 2000) and (c) Extractable organic matter in $\mathrm{mgr} / \mathrm{gr}(\mathrm{EOM})$ are plotted against tops of the sampling intervals. The horizontal swathe encompasses the zone where thermochemical conditions are appropriate for precipitation of high MS magnetic minerals (d) Normalized magnetic susceptibility curve (heating and cooling) measured in air and (e) continuous low temperature magnetic susceptibility measurements for anomalous level $625 \mathrm{~m}$. (f) Scanning Electron photomicrograph (topographic images of secondary electrons) showing a spherical aggregate of submicronic crystals of authigenic magnetic minerals (diameters between 5 and 30 $\mu \mathrm{m}$ ) for a magnetic separate from depth level $625 \mathrm{~m}$ (after Aldana et al., 1999).X-ray energy dispersion spectra for this aggregate reveal a Fe composition with total absence of $\mathrm{S}$ and Ti. (after Aldana et al., 1999); (g) Scanning electron photomicrograph showing a magnification of a spherical aggregate for this same MS anomalous depth level (after Aldana et al., 1999).

and they tend to be the major components of biodegraded crude oils (Bailey et al., 1973). Since asphaltenes have not been found in most of the Guafita and La Victoria wells, then oil biodegradation does not seem to be the main process involved in the origin in situ of A-like magnetic anomalies (Díaz et al., 2000).

Figures 2 and 3 show some examples of A-like anomalies for two producer oil wells. In these examples EPR, high and low temperature magnetic susceptibility and SEM analyses have been used to characterize near-surface MS peaks for LVT-4X (Fig. 2) and GF-3X (Fig. 3) from la Victoria and Guafita fields respectively.

Figure 2(a) shows a MS profile versus depth for LVT4X. There is a split of the MS anomaly at $534 \mathrm{~m}$ and $625 \mathrm{~m}$ (Aldana et al., 1999; Diaz et al., 2000). OMFRC and EOM profiles versus depth are presented in Figs. 2(b) and (c) respectively. The OMFRC (spin/gr), distinguished by EPR, is the total amount of free radicals in the sample, namely asphaltenes and kerogens.

For concentration values greater than $2 \times 10^{16} \mathrm{spin} / \mathrm{gr}$ the
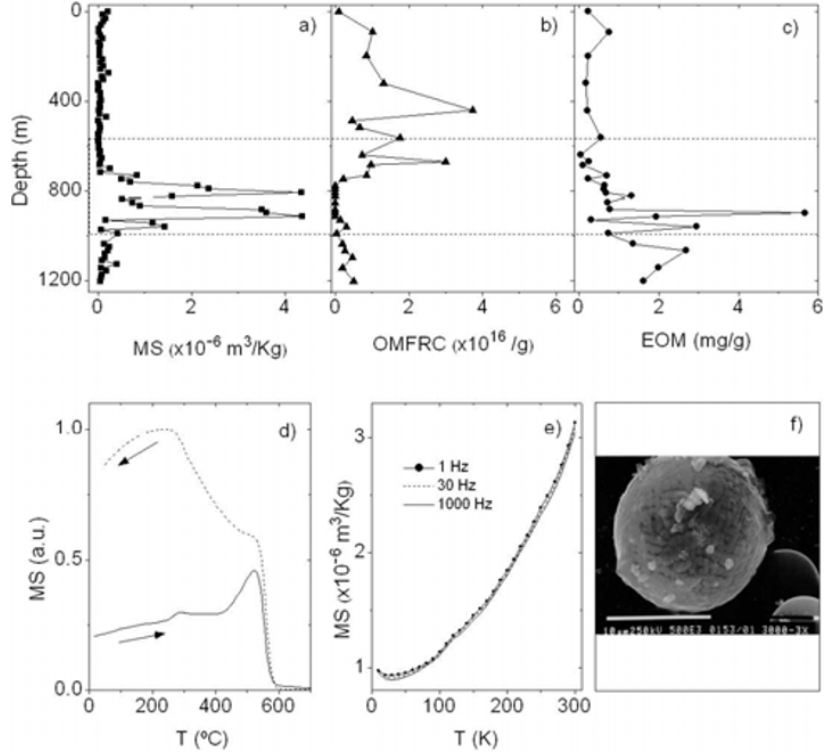

Fig. 3. A-like MS anomaly for producer well GF-3X (a) MS, (b) OMFRC in spin/gr and (c) EOM in mgr/gr are plotted against tops of the sampling intervals. The horizontal swathe encompasses the zone where thermochemical conditions are appropriate for precipitation of high MS magnetic minerals (d) Normalized magnetic susceptibility curve (heating and cooling) measured in air and (e) continuous low temperature magnetic susceptibility measurements for anomalous level $914 \mathrm{~m}$. (f) Scanning Electron photomicrograph (topographic images of secondary electrons) showing a spherical aggregate of submicronic crystals of authigenic magnetic minerals for a magnetic separate from depth level 914 $\mathrm{m}$. X-ray energy dispersion spectra for this aggregate reveal a Fe composition with total absence of $\mathrm{S}$ and $\mathrm{Ti}$.

error in the EPR signal is lower than $10 \%$, whereas for those values below $2 \times 10^{16} \mathrm{spin} / \mathrm{gr}$, such an error could be as high as $20 \%$. For LVT- $4 \mathrm{X}$ there is not a detectable concentration of free radicals (spin/gr) in the EOM, therefore we conclude that most of the OMFRC in these samples are kerogens. A comparison of MS, OMFRC and EOM profiles (Figs. 2(a), (b) and (c)) reveals that all the anomalies lie within a depth interval where thermochemical conditions are appropriate for precipitation of high MS magnetic minerals.

Figure 2(d) shows a thermomagnetic susceptibility curve (heating and cooling), measured in air, for a whole rock sample from MS anomalous level $625 \mathrm{~m}$. In the heating loop (Fig. 2(d)) there is a first rise between 200 and $300^{\circ} \mathrm{C}$ and a second one just below $580^{\circ} \mathrm{C}$ where MS undergoes a major drop revealing the presence of Ti-poor magnetite. Because the irreversible nature of the cooling curve we argue that mineral alteration plays a major role in this behaviour. Indeed, the low temperature rise $\left(200^{\circ} \mathrm{C}\right.$ to $\left.350^{\circ} \mathrm{C}\right)$ could be associated with the change of a $\mathrm{Fe}$-sulphide (e.g. greigite or pyrrothite) or Ti-maghemite to other minerals, at temperatures below $600^{\circ} \mathrm{C}$. The high temperature MS rise in the heating curve $\left(\approx 580^{\circ} \mathrm{C}\right)$, could be explained either by alteration of Fe-bearing minerals and/or as a Hopkinson peak.

Continuous low temperature MS measurements were also performed for this sample (Fig. 2(e)). A well-defined Verwey transition about $120 \mathrm{~K}$ indicates that nearly stoichiometric magnetite, with little or no oxidation at all, is the primary magnetic phase in this MS anomalous level.

Spherical aggregates of submicronic crystals appear to 

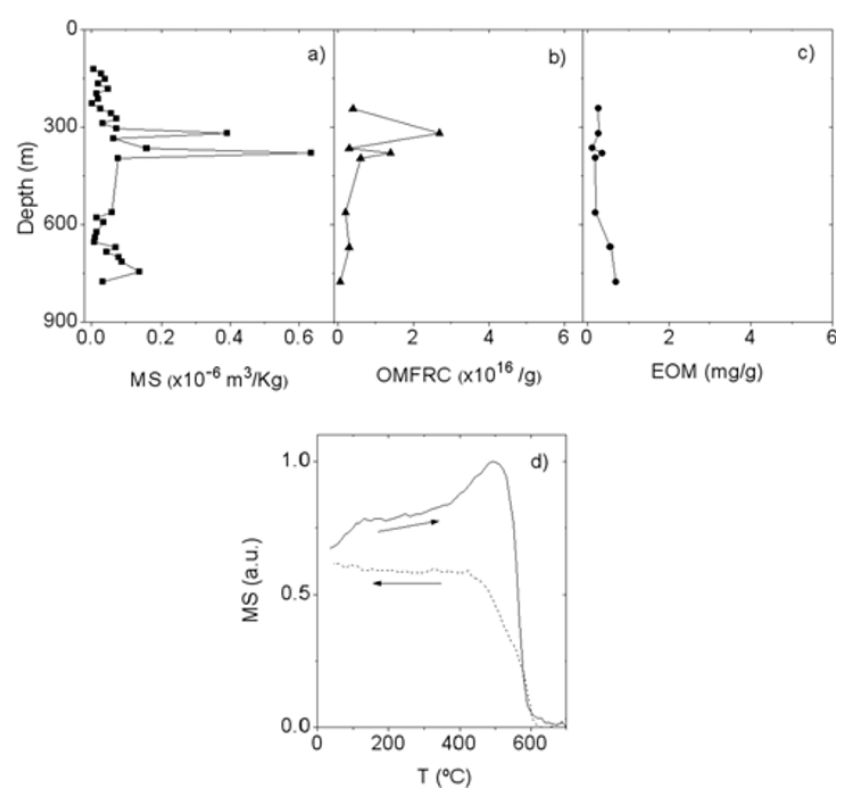

Fig. 4. B-like anomaly for non-producer well GF-8X: (a) MS (after Costanzo-Alvarez et al., 2000), (b) OMFRC in spin/gr (after Diaz et al., 2000) and (c) EOM in mgr/gr plotted against tops of the sampling intervals. (d) Normalized magnetic susceptibility curve (heating and cooling) measured in air for anomalous level $380 \mathrm{~m}$.

be restricted to those levels associated to the MS anomalies. Figure 2(f) shows a photomicrograph of one of such spherules from a magnetic separate taken at anomalous level $625 \mathrm{~m}$. X-ray energy dispersion spectra for this aggregate (Fig. 2(f)) indicate a mostly Fe composition and a total absence of sulfur and/or Ti. Moreover, its granular surface (Fig. 2(g)) probably reflects an ongoing diagenetic process of growing and nucleation (Aldana et al., 1999).

Figure 3 shows the same information as per Fig. 2, for a producer oil well from the Guafita field (GF-3X). MS anomaly is also split into two peaks at $808 \mathrm{~m}$ and 914 m. Once more all the anomalies (MS, OMFRC and EOM) are within a swathe where thermochemical conditions seem to be appropriate for precipitation of high MS magnetic minerals (Figs. 3(a), (b) and (c)). Similar to LVT-4X, there is not a detectable concentration of free radicals (spin/gr) in the EOM, precluding the presence of asphaltenes in these samples.

The thermomagnetic cycle of a sample from anomalous level $914 \mathrm{~m}$ reveals similar shapes for both heating and cooling curves with different MS amplitudes (Fig. 3(d)). A first rise between 200 and $300^{\circ} \mathrm{C}$ is observed in the heating curve, followed by a second one just below $580^{\circ} \mathrm{C}$ where an inflection of MS values indicates the presence of Ti-poor magnetite. The reversibility of the low temperature peak might be related to the presence of Ti-magnetite.

Low temperature MS analyses for this same sample (Fig. 3(e)) shows a largely concealed Verwey transition around $120 \mathrm{~K}$ that could be due to a dominant phase of non-stoichiometric (partially oxidized) magnetite (Özdemir et al., 1993). Figure 3(f) presents a photomicrograph of a spherical aggregate of submicronic Fe-rich crystals for this anomalous level (914 m).

Figure 4 shows rock magnetic and EPR data for oil well

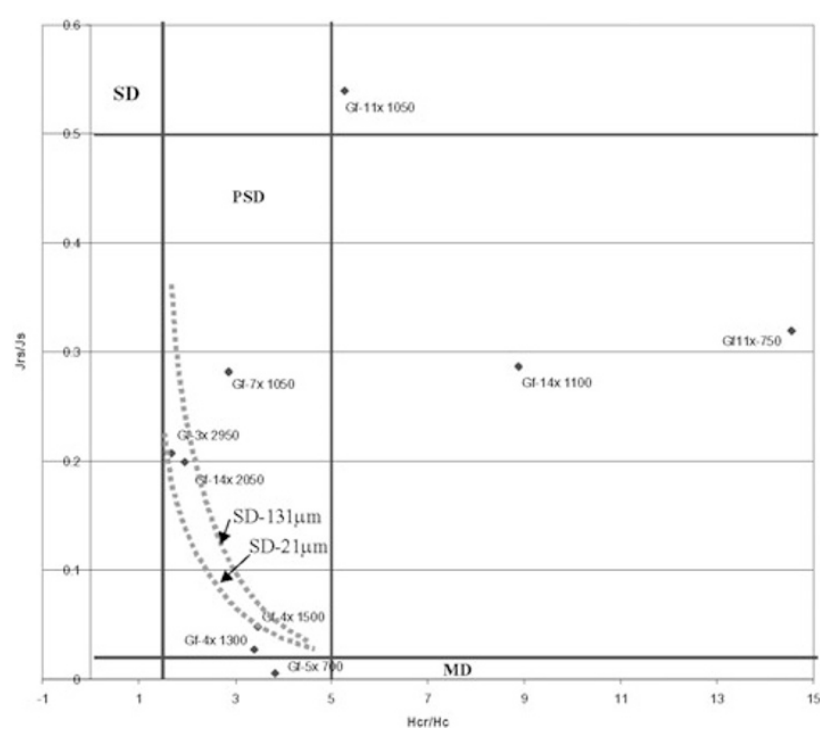

Fig. 5. Hysteresis ratios $J_{r s} / J_{s}$ and $H_{c r} / H_{c}$, measured in whole rock drill cuttings from some Guafita oil wells from. A-like anomalies at GF-3X ( $899 \mathrm{~m}), 4 \mathrm{X}(457$ and $396 \mathrm{~m}), 5 \mathrm{X}(213 \mathrm{~m})$ and 14X (625 m). have been fully characterized by their content of spherical aggregates of Fe-rich magnetic crystals. MS anomaly at GF-7X (320 m) has not been characterized yet. Data from GF-14X (335 m) and GF-11X (320 and $229 \mathrm{~m}$ ) with small MS anomalies that have not been characterized by EPR or SEM analyses either, are also included in this plot. All data points from samples at an A-like anomaly, plus GF-7X $(320 \mathrm{~m})$, lie on the magnetite PSD field. They are arrangedon the trend described by hysteresis parameters of diagenetic spherules from a number of remagnetized limestones (Dunlop, 2002a). Mixing curves (dashed lines) for SD-MD (131 $\mu \mathrm{m})$ and SD-MD $(21 \mu \mathrm{m})$ are also plotted in the background (after Dunlop, 2000b). Hysteresis parameters for the rest of the samples lie on different fields of the plot.

GF-8X (non-producer), with MS peaks at $310 \mathrm{~m}$ and 380 $\mathrm{m}$ (Fig. 4(a)). We argue that this is a B-like anomaly since no spherical aggregates of Fe-rich magnetic minerals have been identified by SEM analyses. The OMFRC values, in the profile of Fig. 4(b), lie within the experimental error of $1 \times 10^{16} \mathrm{spin} / \mathrm{gr}$ and are lower than their counterparts for Alike MS anomalies fully identified in some oil wells from the same field. Moreover, the EOM values for these same samples are very low (Fig. 4(c)).

A thermomagnetic curve, for a whole rock sample from $380 \mathrm{~m}$, was measured in air (Fig. 4(d)) showing a clear drop at $580^{\circ} \mathrm{C}$ that follows a MS increase that could be related to the Hopkinson peak for magnetite. Opposite to A-like MS anomalies in LVT-4X (Fig. 2(d)) and GF-3X (Fig. 3(d)), there is not evidence for a lower temperature rise between $200^{\circ} \mathrm{C}$ and $300^{\circ} \mathrm{C}$ associated to primary ferrimagnetic phases other than Ti-poor magnetite.

As an alternative way of characterizing magnetic phases in anomalous MS levels we have measured room temperature hysteresis parameters $J_{r s} / J_{s}$ and $H_{c r} / H_{c}$ in whole rock drill cuttings from some Guafita oil wells. Results are shown in the Day plot of Fig. 5. Most of these samples come from depth levels where MS anomalies have been completely identified by their content of spherical aggregates of Fe-rich magnetic crystals, namely GF-3X (899 m), 4X (457 and $396 \mathrm{~m}), 5 \mathrm{X}(213 \mathrm{~m})$ and 14X (625 m). There is not additional rock magnetic, EPR or mineralogical information about the MS anomaly observed at GF-7X (320 


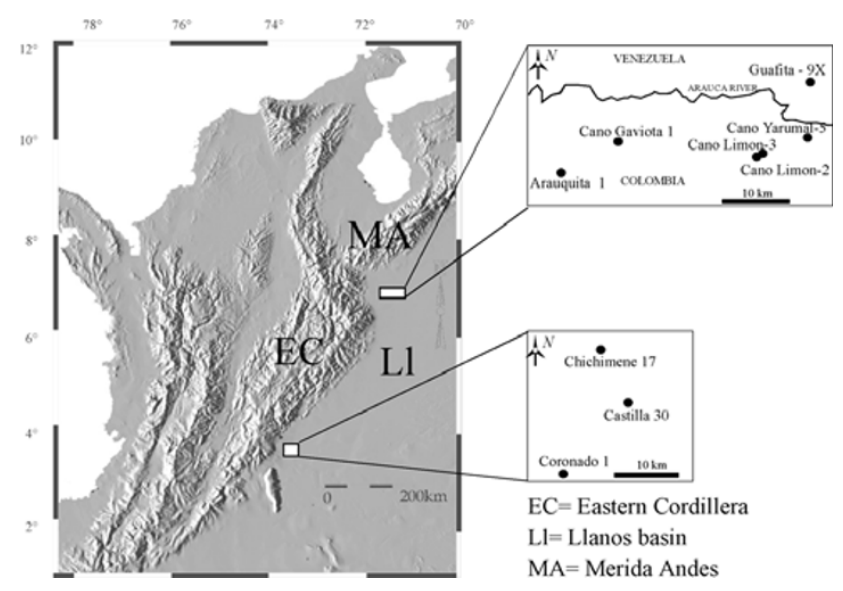

Fig. 6. Sketch map showing the location of the Colombian oil wells and their relative position to the Venezuelan Southwestern border.

$\mathrm{m})$. On the other hand, we have included in the same plot data for GF-14X (335 m) and GF-11X (320 and $229 \mathrm{~m}$ ) from small MS anomalies that have not been characterized by EPR or SEM analyses yet.

All the data points corresponding to A-like anomaly levels, plus GF-7X (320 m), lie on the magnetite PSD field. They are arranged, within the stretch of experimental data dispersion, on the trend described by hysteresis parameters of diagenetic spherules extracted from a number of remagnetised limestones, and the theoretical mixing curves (dashed lines) for SD-MD (131 $\mu \mathrm{m})$ and SD-MD $(21 \mu \mathrm{m})$ presented by Dunlop (2002a and b). Hysteresis parameters for the rest of the samples (e.g. GF-14X (335 m), GF-11X $(229 \mathrm{~m})$ and GF-11X (320 m)) lie on completely different fields of the Day plot. These preliminary results suggest that hysteresis data could be used as an additional criteria to characterize hydrocarbon-induced A-like magnetic contrasts in oil well samples.

\section{Geological Setting of Colombian Oil Wells in the Llanos Basin}

Colombian oil wells for this study are located in the northern and southern part of the Llanos Basin. The northern part of the Llanos Basin (Fig. 6), close to the Venezuelan border, includes the Caño Limón oil field with producer oil well Caño Limón 3. Hydrocarbons produced in this northern part of the basin have similar characteristics to those from La Victoria and Guafita with gravity values ranging from $30^{\circ}$ to $40^{\circ}$ API (light oil). The main geological structure of Caño Limón is a south-plunging half-dome truncated by NE-striking transtensional faults. These faults also play an important role in the sealing of the reservoir traps (Molina, 1991).

The stratigraphic section drilled in these oil fields of the northern Llanos Basin ranges from pre-Cretaceous up to recent strata (Gabela, 1985). Caño Limón producer strata are the sandstones of Carbonera (lower and upper levels) and some Cretaceous beds. Lower Carbonera sandstones are highly productive and hold $80 \%$ of the oil reserves of this field. The source rock is probably formed by marine sediments in a "local kitchen" (Molina, 1991).

The uppermost $1500 \mathrm{~m}$ of Caño Limón 3 correspond
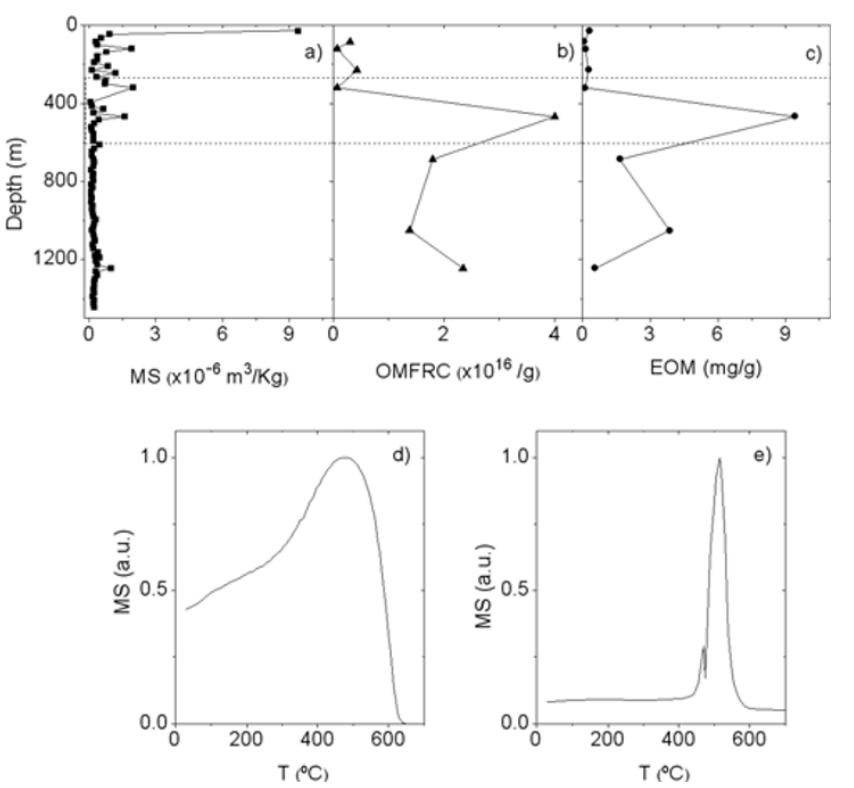

Fig. 7. A-like MS anomaly for heavy oil producer well Castilla 30: (a) MS, (b) OMFRC in spin/gr and (c) EOM in mgr/gr are plotted against tops of the sampling intervals. The horizontal swathe encompasses the zone where biodegradation and thermochemical conditions are appropriate for precipitation of high MS magnetic minerals (d) Normalized magnetic susceptibility curve (heating only) measured in air for a whole rock sample from anomalous level $311 \mathrm{~m}$ and (e) from anomalous level $450 \mathrm{~m}$ :

to the Guayabo Formation, namely conglomerates, lithicbearing sandstones and multicoloured mudstones that were deposited in a continental paleoenvironment. These lithologies grade toward the base to fine and medium-grained quartz sandstones that overly the fine-grained lithologies of the León Formation (i.e. dark to green mudstones).

Oil well Castilla 30, in the southern part of the Llanos basin, is close to the foothills of the Eastern Cordillera and within the Apiay-Ariari sub Basin. The sedimentary sequence in the southern Llanos Basin ranges from Paleozoic to recent strata. The reservoir rocks are Upper Cretaceous non-marine beds and few sandstones from the lower interval of the Carbonera Formation. Hydrocarbons have gravity values ranging from $20^{\circ}$ to $30^{\circ}$ API (heavy oil), high sulphur content and elevated biodegradation. Their source rocks seem to be marine carbonates from the Eastern Cordillera (Rangel et al., 1991, 2003).

In Castilla 30 the drill cuttings analysed also belong to Carbonera and León Formations and they include black laminated mudstones at the base grading to mottled and multicoloured mudstones toward the top that are interbedded with fine- to medium-grained quartz sandstones with some fragments of coal.

\section{Preliminary MS, EPR and EOM Results of Some Colombian Oil Wells}

Figures 7 and 8 present MS anomalies for Castilla 30 (Fig. 7) and Caño Limón 3 (Fig. 8). The latter is located in the vicinity of its Venezuelan counterparts from La Victoria and Guafita. Magnetic contrasts for these two wells have been characterized by OMFRC, EOM and high temperature magnetic susceptibility analyses. 

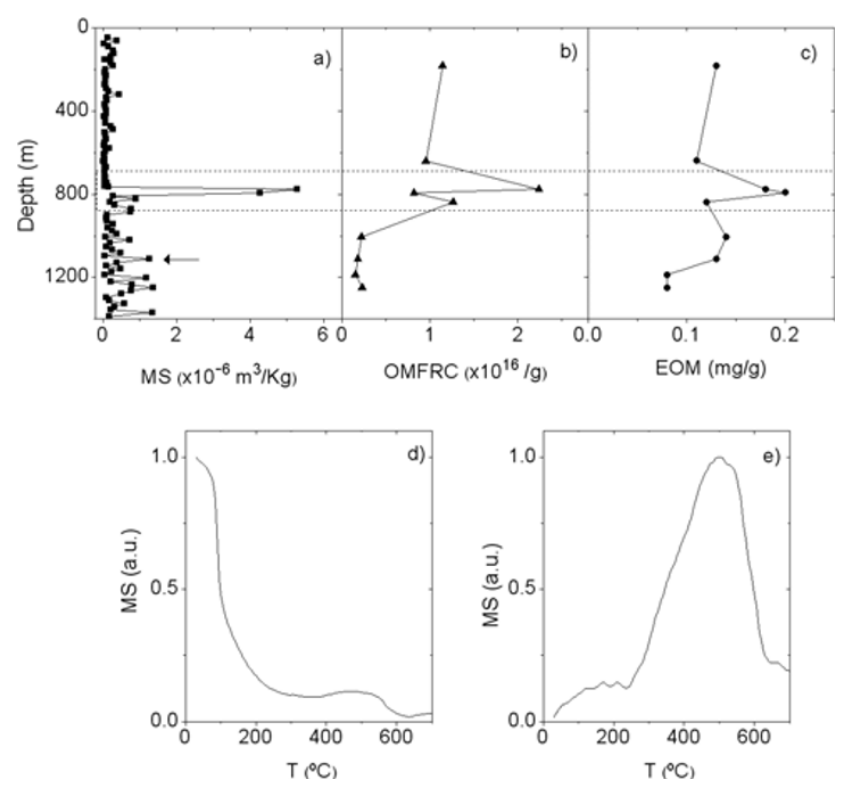

Fig. 8. A-like MS anomaly for light oil producer well Caño Limon (a) MS, (b) OMFRC in spin/gr and (c) EOM in mgr/gr are plotted against tops of the sampling intervals. The horizontal swathe encompasses the zone where thermochemical conditions are appropriate for precipitation of high MS magnetic minerals (d) Normalized magnetic susceptibility curve (heating only) measured in air for a whole rock sample from anomalous level $765 \mathrm{~m}$ and (e) from anomalous level $1250 \mathrm{~m}$.

Figure 7(a) shows the MS profile for producer well Castilla 30 located in the southern flank of the study area (Fig. 6). There is a shallow and rather small MS anomaly at depth level $311 \mathrm{~m}$. Major OMFRC and EOM peaks (Figs. 7(b) and (c)) are centred at slightly deeper levels that coincide with a lower MS peak $(450 \mathrm{~m})$. In this well, all the EOM obtained (except for level $65 \mathrm{~m}$ ) appears to be an extremely viscous black bitumen very difficult to extract Therefore, EOM concentrations shown in Fig. 7(c) must be higher than the ones we have been actually able to collect. The EOM obtained for samples from $450 \mathrm{~m}$ and $1000 \mathrm{~m}$ show high concentrations of free radicals and precipitate asphaltenes when heptane is added to them. This might be an indication that also biodegradation could be taking place in this reducing zone.

Thermomagnetic curves were obtained for Castilla 30 (only heating data are shown in Figs. 7(d) and e). A sample from anomalous level $311 \mathrm{~m}$ clearly reveals a magnetic phase with a major susceptibility drop at about $600^{\circ} \mathrm{C}$, slightly higher of the nominal Curie temperature for stoichiometric magnetite (Fig. 7(d)). On the other hand, for a sample from a lower MS peak, located at approximately $450 \mathrm{~m}$, the heating curve (Fig. 7(e)) suggests the formation of a new magnetic phase (temperatures above $400^{\circ} \mathrm{C}$ ) with a Curie point of approximately $520^{\circ} \mathrm{C}$ (e.g. Ti-poor magnetite). This magnetic phase might have resulted from thermochemical alteration of non magnetic Fe-bearing minerals such as clays or pyrite.

Caño Limón 3 is located in the northern flank of the study area (Fig. 6). The MS log in Fig. 8(a) shows a peak centred at approximately $765 \mathrm{~m}$. Opposite to Castilla 30, in Caño Limón 3 OMFRC and EOM analyses show low amplitude peaks at MS anomalous levels (Figs. 8(b) and (c)). Thus,

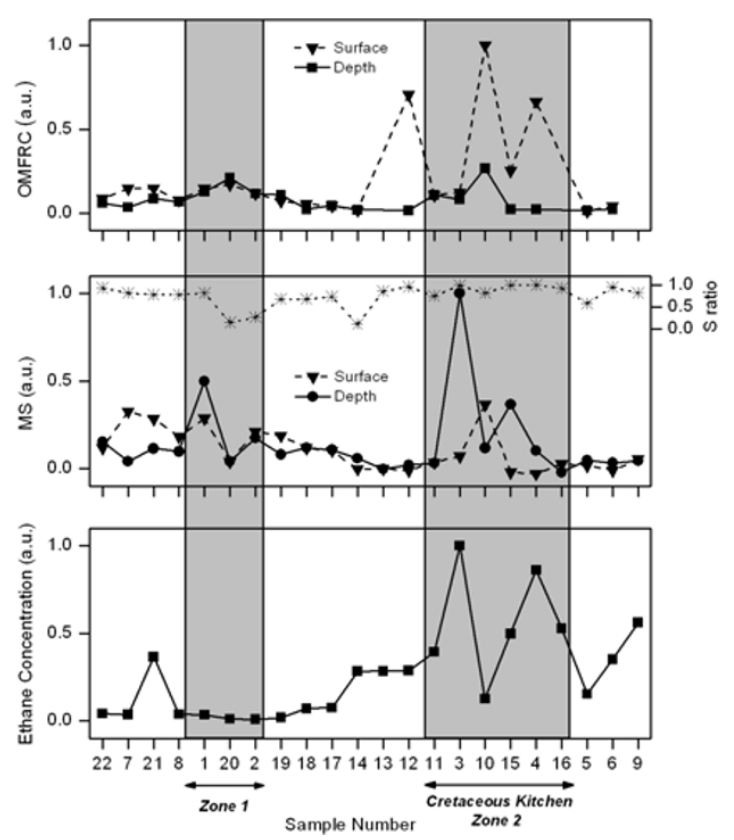

Fig. 9. (a) Normalized OMFRC variation for surface and depth (1-2 meters) soils from a oil prospective area in the southwestern Venezuelan Andean Range. (b) S-ratio and normalized MS (after Gonzalez et al., 2002; Aldana et al., 2003) and (c) Ethane concentration (Romero et al., 2000). These values have been plotted against their relative positions sequentially arranged from north to south. A conspicuous MS and OMFRC southern anomaly coincides with the zone of highest ethane concentration that overlies a "Cretaceous kitchen" (Romero et al., 2000).

the EPR evidence does not seem to be conclusive enough in establishing a direct link between the MS peaks and the underlying reservoir.

EOM for Caño Limón 3 is yellowish and slightly viscous. The marked contrast between the highly viscous and black EOM extracted in Castilla 30 and that obtained for Caño Limón 3, are probably related to the type of hydrocarbons produced by each of these wells, namely heavy in Castilla 30 and light in Caño Limón 3. We argue that such a difference must be also the reason for their contrasting OMFRC and EOM amplitudes.

Figure 8(d) shows a thermomagnetic curve (heating only) measured in air, for a sample from Caño Limón 3 level $765 \mathrm{~m}$ (MS anomaly). This curve has two major drops at about $100^{\circ} \mathrm{C}$ and $580^{\circ} \mathrm{C}$, indicating both goethite and $\mathrm{Ti}$ poor magnetite respectively. Conversely, the heating curve corresponding to the small MS peak at $1097 \mathrm{~m}$ (Fig. 7(e)), shows no evidence for primary ferrimagnetic minerals. Instead there is a magnetic phase that seems to form upon heating with a progressive rise of susceptibility values starting at temperatures over $200^{\circ} \mathrm{C}$. The major inflection at $580^{\circ} \mathrm{C}$ and the residual susceptibility tail over $600^{\circ} \mathrm{C}$ suggest that these secondary Fe-oxides are Ti-poor magnetite and hematite.

\section{MS, EPR and EOM Results from Soil Samples from the Southern Flank of the Venezuelan Andean Range}

MS and OMFRC results, for soil samples from an oil prospective area in the southern flank of the Venezuelan An- 
dean Range, have been reported by González et al. (2002) and Aldana et al. (2003). They carried out MS and EPR analyses in poorly consolidated sands and muds, sampled at shallow depths (down to about 2 meters), from 22 sites evenly distributed all over the region.

Figure 9 shows MS and OMFRC normalized data (after González et al., 2002; Aldana et al., 2003) and ethane concentrations (Romero et al., 2000) for some of these sites, plotted against their relative positions sequentially arranged from north to south. From these profiles it is clear that MS and OMFRC values vary in like fashion. A conspicuous MS and OMFRC southern anomaly coincides with the zone of highest ethane concentration that overlies a "Cretaceous kitchen" that is the subsurface area where source rock has reached appropriate conditions of pressure and temperature to generate hydrocarbons (Romero et al., 2000).

Saunders et al. (1999) have previously argued that seepage of light hydrocarbons (e.g. methane and butane) involves the rising of microbubbles through a water-filled network of fractures, joints and bedding planes. Consequently, hydrocarbon leakage could induce the vegetation stress seen as tonal anomalies in remote sensing images.

Field reflectance analyses previously performed in this region suggest the dominant presence (about $70 \%$ ) of the fern Pteridium Aquilinum in the ethane anomalous area (Arrieche et al., 2000). A NS-striking trend, probably related to stressed fern, has been identified by the spectral angle mapper (SAM). This also coincides with the tonal anomalies and the highest ethane concentration values above the Cretaceous kitchen.

González et al. (2002) and Aldana et al. (2003) have argued that OMFRC peaks could be linked to degradation and/or alteration of organic matter induced by hydrocarbon gas leakage, whose surface expression is the stressed fern. High concentration of free radicals are usually found in water-logged or poorly-drained soils where reducing conditions prevail (Schnitzer, 1978). Similarly, MS anomalies, mostly due to the presence of magnetite according to high temperature susceptibility analyses also performed by González et al. (2002), could be related to the reducing environment produced by vertical migration of hydrocarbon gases. They did not detect the presence of Fe-sulphides such as greigite and pyrrothite that are quite common in this kind of seepage areas.

A distinction was observed for MS and OMFRC values when measured in soil samples taken at surface and at depths of approximately 1 to 2 meters. For MS, the difference between surface and depth amplitudes could be due to weathering effects. A similar tendency is observed for OMFRC when measured at these two depth levels. In the reducing zone 2 (Fig. 9), above the Cretaceous kitchen, we found higher OMFRCs in surface samples. Two possible causes might be responsible for such values as well as for the observed OMFRC anomalies, namely an increase of the organic matter content, or an increase of the free radical concentration due to a change of the type of organic matter. To determine the actual reason behind such a behaviour demineralisation treatments were performed on selected samples (Aldana et al., 2003).

Thus, it was found that for depth samples, the ratio be- tween the anomalies detected in zone 1 relative to those in zone 2 is the same independently of the demineralisation treatment. These results indicate that the OMFRC anomalies of depth samples are associated to an increase of the free radical concentration of the organic matter. This increase is possibly related to the reducing environment induced by the underlying Cretaceous kitchen.

For the surface samples, OMFRC values in zone 1 largely enhance after demineralisation and the ratio between anomalies at both zones is different after demineralisation treatments. In this case, besides the process indicated above, an increase of the free radical concentration due to a change in the type of organic matter is also expected.

The good correlation of independent data (i.e. magnetic, EPR and geochemical) observed in the three profiles of Fig. 9, illustrates the possible use of this kind of integrated near surface studies as a fast, reliable and inexpensive first exploratory approach to asses the oil and gas potential of an area of prospective interest.

\section{Concluding Remarks}

It has been hypothesized that magnetite, in a variety of sedimentary environments, may have resulted from organic matter oxidation coupled with Fe (III) reduction (Zhang et al., 1997). On the other hand, our results in soil samples from the Andean Range, suggest that leakage of hydrocarbon gas could be associated to degradation or alteration of the organic matter (Aldana et al., 2003). We argue that $\mathrm{Fe}(\mathrm{III})$, together with reduced organic matter, should have existed at A-like anomalous levels. Then, a net transfer of electrons from the altered organic matter to Fe (III) occurred (Walker, 1984) with the consequent production of EOM and Fe (II) magnetic minerals (e.g. Ti-poor magnetite). Due to the net transfer of electrons from the organic matter, those depth levels with the highest OMFRC values are not always the same that show MS and EOM peaks. Actually, MS, EOM and OMFRC anomalies define a rather broad reducing zone where the appropriate conditions for authigenesis of primary Fe-oxides have taken place (Díaz et al., 2000). Such a reducing zone is indicated by a swathe that encompasses the MS, OMFRC and EOM profiles of Figs. 2, 3, 7 and 8(a), (b) and (c) (i.e. Venezuelan: LVT-4X and GF-3X and Colombian Caño Limón 3 and Castilla 30). Moreover, the amplitude of these anomalies seems to be related to the characteristics of the oil (i.e. light or heavy), as previously discussed for Caño Limón 3 and Castilla 30.

On the other hand, GF-8X shows a largely suppressed OMFRC anomaly that lies within the range of the EPR experimental error when compared, at the same scale, with the MS, OMFRC and EOM anomalies for LVT-4x and GF8X (Figs. 2 and 3(a), (b) and (c)). In addition, there is not a detectable EOM anomaly in GF-8X whatsoever. Thus we argue that, a different process that cannot be related to hydrocarbon-induced magnetic authigenesis, must have produced MS peaks in this oil well. The absence of spherical aggregates of submicronic Fe-rich magnetic crystals at MS anomalous levels (i.e. 310 and $380 \mathrm{~m}$ ) seems to be the definitive criteria to conclude that this is a B-like anomaly related perhaps to a lithological contrast.

It is important to emphasize that the relationship between 
oil-producing areas and magnetic microanomalies, obtained by high sensitivity aeromagnetic measurements, is far from being direct. In fact, these studies must be always complemented by MS analyses of drill cuttings and soils in order to preclude any possible interference such as cultural iron contamination or lithological contrasts not related with hydrocarbons.

Our contribution to the study of these microanomalies is predominantly the set of criteria (i.e. petrographic analyses of mineral compositions, EPR, EOM, SEM and hysteresis parameters) we have been exploring in the last few years, in order to link, with a minimum uncertainty, near-surface MS anomalies with the underlying reservoir.

At present, our ongoing research is focusing on the complexities that come up with the application of these criteria to different oil fields, with a variety of crude oils and subsurface structures that could have an important influence on migration and/or seepage of hydrocarbons.

Acknowledgments. Samples were generously provided by E. Del Pino, D. Funes and F. Castillo (PDVSA, Pto. La Cruz, Venezuela), I. Romero, N. Nevado and F. Fernández (INTEVEP-PDVSA, Los Teques, Venezuela), D. García (Instituto Colombiano del Petróleo, Bucaramanga, Colombia) and F. Ortega (Litoteca Nacional, Bucaramanga, Colombia). They also made available important unpublished geological and geophysical information from Venezuela and Colombia. We are grateful to all the people and laboratories that have contributed to this research. Specially to M. Jackson and S. Banerjee (Institute of Rock Magnetism, Minnesota, USA), W. Williams (University of Edinburgh, Edinburgh, Scotland) and M. Hernández (Ingeominas, Bogotá, Colombia). The thoughtful work and enthusiasm supplied by our alumnae: D. Vitielo, G. Gómez, L. Colmenares, O. Aristeguieta, E. Aconcha, F. González and P. Sequera played an important role in the success of these studies. This research was partially funded by PDVSA (Venezuela), INTEVEPPDVSA (Venezuela), Corporación Geológica ARES (Colombia) and Decanato de Investigación y Desarrollo (Universidad Simón Bolívar, Venezuela). Hysteresis and low temperature susceptibility measurements were carried out by M.A. thanks to a 10-days visiting fellowship to the IRM, that is funded by the NSF, the Keck Foundation and the University of Minessota.

\section{References}

Aizaenshtat, Z., I. Pinsky, and B. Spiro, Electron spin resonance of stabilized free radicals in sedimentary organic matter, Organic Geochemistry, 9, 321-329, 1986.

Aldana, M., V. Costanzo-Alvarez, D. Vitiello, L. Colmenares, and G. Gomez, Framboidal magnetic minerals and their possible association to hydrocarbons: La Victoria oil field, Southwestern Venezuela, Geofísica Internacional, 38, 137-152, 1999.

Aldana, M., M. Díaz, V. Costanzo-Alvarez, F. González, and I. Romero, EPR studies in soil samples from a prospective area at the Andean Range, Venezuela, Revista Mexicana de Física, 49, Suplemento, 3, 4-6, 2003.

Angel, B. R. and W. E. J. Vincent, Electron spin resonance studies of iron oxides associated with the surface of kaolins, Clays, Clay Minerals, 26, 263-272, 1978.

Arrieche, M., A. Vera, I. Romero, M. González, and L. Galvao, Use of remote sensing and field reflectance data integrated with surface geochemistry and geology for detecting possible areas of hydrocarbon presence. VII Simposio Bolivariano de Exploración Petrolera en las Cuencas Subandinas, Caracas, Venezuela, 767-782, 2000.

Bailey, N. J. L., A. M. Jobson, and M. A. Rogers, Bacterial degradation of crude oil: Comparison of field and experimental data, Chemical Geology, 11, 203-221, 1973.

Benthiem, R. H. and R. D. Elmore Wyoming: a possible relationship with hydrocarbons, Geophys. Res. Lett., 14, 323-326, 1987.

Boughriet, A., B. Ouddane, and M. Wartel, Electron spin resonance investigations of Mn compounds and free radicals in particles from the Seine river and its estuary, Marine Chemistry, 37, 149-169, 1992.

Burguess, B. A., N. D. Chasteen, and H. E. Gaudette, Electron paramagnetic resonance spectroscopy: A suggested approach to trace metal analysis in marine environments, Environmental Geology, 1, 171-180, 1975.

Chigné, N., Aspectos relevantes de la exploración en Apure, Memorias del VI Congreso Geológico Venezolano, 2891-2927, 1985.

Costanzo-Alvarez, V., M. Aldana, O. Aristeguieta, M. C. Marcano, and E. Aconcha, Studies of magnetic contrasts in the Guafita oil field (southwestern Venezuela), Phys. Chem. Earth (A), 25(5), 437-445, 2000.

Díaz, M., M. Aldana, V. Costanzo-Alvarez, P. Silva, and A. Pérez, EPR and Magnetic Susceptibility studies in well samples from some Venezuelan oil fields, Phys. Chem. Earth (A), 25(5), 447-453, 2000.

Dunlop, D. J., Theory and application of the Day plot $\left(M_{r s} / M_{s}\right.$ versus $\left.\mathrm{H}_{c r} / H_{c}\right)$ 1. Theoretical curves and tests using titanomagnetite data, $J$. Geophys. Res., 107(B3), DOI:10.1029/2001JB000486, 2002a.

Dunlop, D. J. Theory and application of the Day plot $\left(M_{r s} / M_{s}\right.$ versus $\left.H_{c r} / H_{c}\right)$ 2. Application to data for rocks, sediments and soils, J. Geophys. Res., 107(B3), DOI 10.1029/2001JB000487, 2002b.

Elmore, R. D., M. H. Engel, L. Crawford, K. Nick, S. Imbus, and Z. Sofer, Evidence for a relationship between hydrocarbons and authigenic magnetite, Nature, 325, 428-430, 1987.

Elmore, R. D., S. W. Imbus, M. H. Engel, and D. Fruit, Hydrocarbons and magnetizations in magnetite, Applications of Paleomagnetism to Sedimentary Geology, SEPM Special Publication, 49, 181-191, 1993.

Foote, R. S., Significance of near-surface magnetic anomalies, in Unconventional Methods in Exploration for Petroleum and Natural Gas, edited by M. J. Davidson and B. M. Gottlied, Southern Methodist University, Institute for Study of Earth and Man, Dallas, pp. 12-24, 1984.

Foote, R. S., Correlations of borehole rock magnetic properties with oil and gas producing areas, Association of Petroleum Geochemical Explorationists Bulletin, 3, 114-134, 1987.

Foote, R. S., Use of magnetic field aids oil search, Oil \& Gas Journal May, 4, 137-141, 1992.

Foote, R. S., Relationship of near-surface magnetic anomalies to oil- and gas-producing areas, in Hydrocarbon Migration and its Near-surface Expression: AAPG Memoir, 66, edited by D. Schumacher and M. A. Abrams, pp. 111-126, 1996.

Gabela, V., Campo Caño Limón, Llanos Orientales de Colombia. II Simposio Bolivariano de Exploración Petrolera en las Cuencas Subandinas, Cartagena de Indias, Colombia, pp. 29, 1985.

Gonzalez de Juana, C., J. M. Iturralde de Arozena, and C. Picard, Geología de Venezuela y de sus Cuencas Petrolíferas. 1rs ed. Foninves, Caracas, Venezuela, Vol. 2, 407 pp., 1980.

González, F., M. Aldana, V. Costanzo-Alvarez, M. Díaz, and I. Romero, An Integrated Rock Magnetic and EPR Study in Soil Samples From a Hydrocarbon Prospective Area, Phys. Chem. Earth (A), 27(25-31), 193-199, 2002.

Granwehr, J., P. G. Weidler, and A. U. Gehring, The fate of structure-bound $\mathrm{Mn}^{2+}$ during decomposition of dolomite and in the resulting conversion products: an EPR study, American Mineralogist, 89, 785-789, 2004.

Hall, P. L., The application of electron spin resonance spectroscopy to studies of clay minerals. 1. Isomorphous substitutions and external surface properties, Clay Minerals, 15, 321-335, 1980.

Hall, S. A. and I. Evans, Palaeomagnetic and rock magnetic properties of hydrocarbon reservoir rocks from the Permian Basin, southeastern New Mexico in Paleomagnetic Applications in Hydrocarbon Exploration and Production, edited by P. Turner and A. Turner, Geological Society Special Publication, 98, pp. 79-95, 1995.

Jonas, M., Concepts and methods of ESR dating, Radiation Measurements, 27, 943-973, 1997.

Kiser, G. D., Relaciones estratigráficas de la Cuenca Apure/Llanos con áreas adyacentes, Venezuela Suroeste y Colombia oriental, Monografía I, Sociedad Venezolana de Geólogos, 1989.

Lumsden, D. N. and R. V. Lloyd, An update of ESR spectroscopy studies of dolomite origin, Sedimentology and Geochemistry of Dolostones, SEPM Special Publication, 43, 3-10, 1988.

McCabe, C., S. Roger, and B. Saffer, Occurrence of secondary magnetite within biodegraded oil, Geology, 15, 7-10, 1987.

Meads, R. E. and P. J. Malden, Electron spin resonance in natural kaolinites containing $\mathrm{Fe}^{3+}$ and other transition metal ions, Clay Minerals, 10, 313-345, 1975.

Molina, J., Evolución Estructural, Migración, Entrampamiento y Remigración de los hidrocarburos de Caño Limón, Colombia. IV Simposio Bolivariano de Exploración Petrolera en las Cuencas Subandinas, Bogotá, Colombia, pp. 14, 1991. 
Otamendi A. M., Díaz M., Costanzo-Álvarez V., M. Aldana, and A. Pilloud, EPR Stratigraphy applied to the study of two marine sedimentary sequences in Southwestern Venezuela, Physics of the Earth and Planetary Interiors, 154, 243-254, 2006

Özdemir, Ö, D. J. Dunlop, and B. M. Moskowitz, The effect of oxidation on the Verwey transition in magnetite, Geophys. Res. Lett., 20, 16711674, 1993.

Pawse, C. T., S. Beske-Diehl, and S. A. Marshall, Use of magnetic hysteresis properties and electron spin resonance spectroscopy for the identification of volcanic ash: a preliminary study, Geophys. J. Int., 132, 712-720, 1998.

Rangel, A., B. Giraldo, A. Blandon, J. C. Ramon, and F. Cordoba, Evaluación Geoquímica de la Cuenca de los Llanos Orientales. IV Simposio Bolivariano de Exploración Petrolera en las Cuencas Subandinas, Bogotá, Colombia, pp. 25, 1991.

Rangel, A., C. Escalante, and C. Mora, Evaluación Geoquímica Integrada de los Gases y Crudos Colombianos: un nuevo enfoque para la Exploración de Hidrocarburos. VIII Simposio Bolivariano de Exploración Petrolera en las Cuencas Subandinas, Cartagena de Indias, Colombia, pp. 285-295, 2003.

Rink, W. J., Electron spin resonance (ESR) dating and ESR applications in Quaternary Science and Archaeometry, Radiation Measurements, 27, 975-1025, 1997.

Rochat, P., A. Rosero, R. Gonzalez, I. Florez, M. Lozada, and R. Petton, Thrust Kinematics of the Tangara/Mundonuevo area: new insight from apatite fission tracks analysis. VIII Simposio Bolivariano de Exploración Petrolera en las Cuencas Subandinas, pp. 147-154, 2003.

Romero, I., C. Zambrano, M. González, J. Pérez, E. Novoa, A. González, and M. Odehnal, Modelo integrado geoquímico-estructural (preliminar) en el Flanco Surandino. VII Simposio Bolivariano de Exploración Petrolera en las Cuencas Subandinas, Caracas, Venezuela, pp. 566-576, 2000.

Saunders, D. F. and S. A. Terry, Onshore exploration using the new geochemistry and geomorphology, Oil \& Gas Journal Sept. 16, 126-130, 1985.

Saunders, D. F., K. R. Burson, and C. K. Thompson, Observed relation of soil magnetic susceptibility and soil gas hydrocarbon analyses to subsurface hydrocarbon accumulations, The American Association of Petroleum Geologists Bulletin, 75, 389-408, 1991.

Saunders, D. F., K. R. Burson, and C. K. Thompson, Model for hydrocarbon microseepage and related near-surface alterations, The American Association of Petroleum Geologists Bulletin, 83, 170-185, 1999.

Schnitzer, M., Humic substances: Chemistry and reactions, in Soil Organic Matter, edited by M. Schnitzer and S. U. Khan, pp. 1-58, 1978.

Walker, J. C. G., Suboxic diagénesis in banded iron formations, Nature, 309, 340-342, 1984.

Zhang, Ch., S. Liu, T. J. Phelps, D. R. Cole, J. Horita, S. M. Fortier, M. Elless, and J. Valley, Physiochemical, mineralogical, and isotopic characterization of magnetite-rich iron oxides formed by thermophilic iron-reducing bacteria, Geochim. Cosmochim. Acta, 61, 4621-4632, 1997.

V. Costanzo-Alvarez (e-mail: vcosta@usb.ve), M. Aldana, M. Díaz, G. Bayona, and C. Ayala 